\title{
Estimation of urinary citrate, calcium and PH levels in diabetic patients and the risk of urinary stone formation in correlation with type of disease
}

\author{
https://doi.org/10.32792/utq/utj/v0l11/1/3
}

Zainab Ali kadhem, Abbas Mohsin Abbas and Murtada Hafedh Hussein MSc. biochemistry, Department of Medical Chemistry, College of Medicine, Thi- Qar University, Iraq .

MSc. biochemistry, Department of Chemistry, College of science, Thi- Qar University, Iraq .

MSc. biochemistry, Department of Pathological Analysis, College of science, Thi- Qar University, Iraq

\begin{abstract}
Objectives : This study designed to evaluate urinary value of calcium, citrate, and the $\mathrm{PH}$ then assess the relation between urinary calcium and citrate with fasting blood sugar and evaluate the risk of renal stones in diabetes patients dependent of their type (type 1 and type 2).
\end{abstract}

Patients and methods :Fifty four diabetic patients selected with no history of hypertension, no heart disease, and no other disease or smoking. Fasting blood and 24 hour urine samples were collected to evaluate fasting blood sugar, urine calcium, urine citrate , and urine $\mathrm{PH}$.

Results: 30 male $(55.6 \%)$ and 24 women $(44.4 \%)$ in a total of 54 patients with diabetes mellitus, aged between 20-65 years. The statistic results of DM type are 25(46.3\%) with type 1 and $29(53.7 \%)$ with type 2. F.B.S increased (11.79 $\pm 4.66 \mathrm{mmol} / \mathrm{l})$ significantly (P < $0.01)$ as compared to healthy individuals $(4.5 \pm 0.98 \mathrm{mmol} / \mathrm{l})$. Urine calcium significantly elevated in DM patients $(6.184 \pm 1.67 \mathrm{mmol} /$ day $)$. Urine citrate significantly decreased ( $0.47 \pm 0.57 \mathrm{mmol} /$ day $)$ comparing with healthy individual $(2.22 \pm 0.55 \mathrm{mmol} /$ day $)$. Urine $\mathrm{PH}(4.46 \pm 0.50)$ significantly $(\mathrm{P}<0.05)$ lower than control $(6.16 \pm 0.38)$. There are a positive correlation between F.B.S and urine calcium for all patients but there are adverse correlation with urinary citrate. There are no significant differences $(\mathrm{P}>0.05)$ in FBS and urine calcium between DM types except in urine citrate $(\mathrm{P}<0.01)$, and urine $\mathrm{PH}(\mathrm{P}<$ 0.05 ) significantly decreased in type 2.

Conclusion: Findings from this study suggest that poor control of diabetes result in increased the risk of urinary stone by causing hypercalciuria, hypocitruturia, and urine 


\section{University of Thi-Qar Journal Vol.11 No.1 Mar 2016 \\ Web Site: https://jutq.utq.edu.iq/index.php/main Email: journal@jutq.utq.edu.iq}

acidity . Urine citrate concentration and $\mathrm{PH}$ level are more sensitive to the metabolic changes in diabetic patients and correlated with type of disease, their levels in type 2 diabetic patients are significantly lower than type 1 , so both types of diabetes have relative risk of prevalent stone disease but type 2 diabetic patients predisposes to calcium Urolithiasis more than type 1 .

\section{تقدير مستوى الستريت والكالسيوم والدالة الحامضية في إدرار مرضى السكري ومدى علاقة خطورة تكون حصى الكلى بنوع مرض السكري}

$$
\text { زينب علي كاظم , عباس محسن عباس , مرتضى حافظ حسين }
$$

الاهداف :صمدت الدراسة الحالية لقياس تركيز كلا من الكالسيوم والستريت ودالة الحامضية في ادرار مرضى السكري

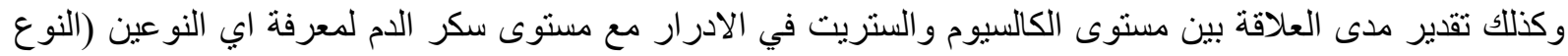

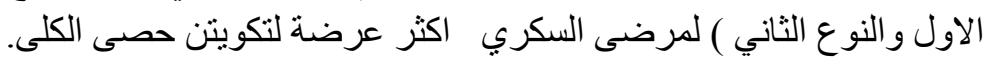

طريقة العمل :جمع حوالي 54مريض مصاب بداء السكري لايعاني من امر اض ارتفاع ضغط الدم او امر اض قلب اضل او اي

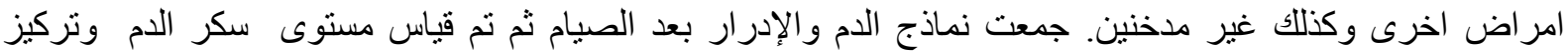

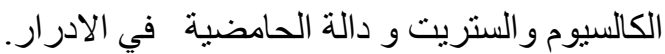

النتائج :30 رجل (55,6 \% \%) و 24 امر اءة (44,4\%) من مجموع 54 مريض تنز اوح أعمار هم بين 20 -65 سنة . نتائج

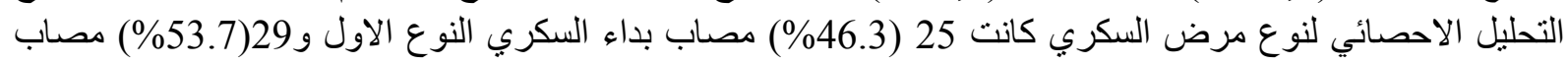
بالنوع الثناني ـ الزيادة في تركيز سكر الدم الصيامي ( 66 ـ

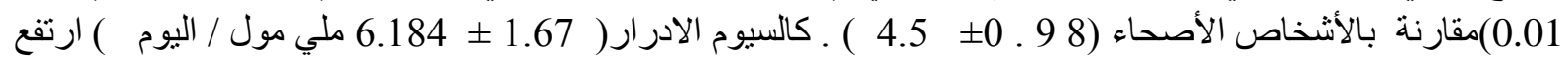

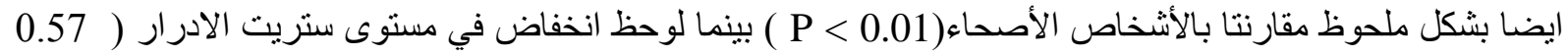

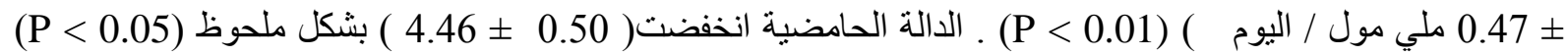

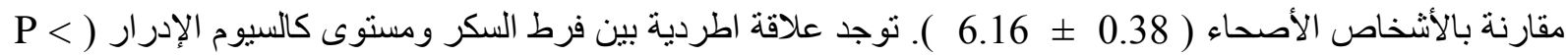

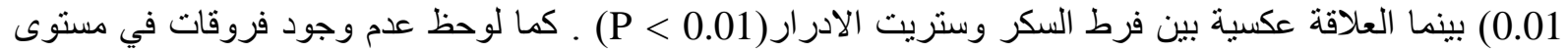

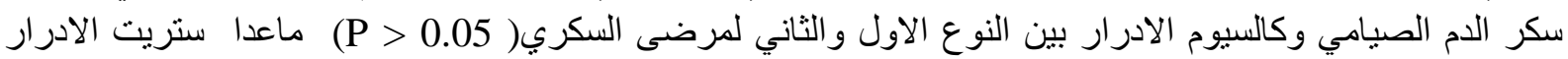

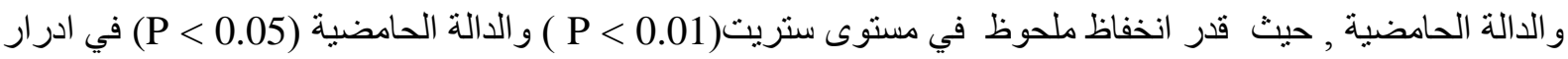

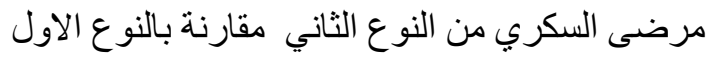

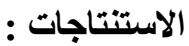

كن النتائج السابقة نستنتج ان فرط السكر الغير مسيطر عليه يزيد من احتمالية تكون الحصى نتيجة لزيادة مستوى

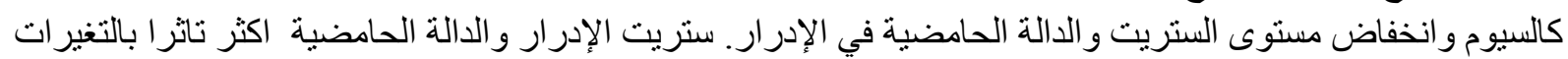

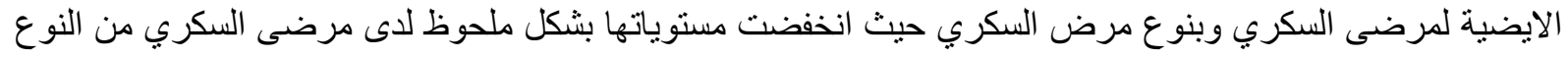
الثاني , و عليه فان كلا نو عي مرض الإن السكري عرضة لخطورة تكون حصى الكالسيوم لكن النوع الثناني اكثر خطورة . 


\section{University of Thi-Qar Journal Vol.11 No.1 Mar 2016}

Web Site: https://jutq.utq.edu.iq/index.php/main Email: journal@jutq.utq.edu.iq

$$
\text { الكلمة مفتاح : نوع مرض السكري ,حصى الكلى ,كالسيوم الإدرار , ستريت الإدرار, الدالة الحامضية. }
$$

Key word : Diabetes mellitus type, Renal stones, Urine calcium, Urine citrate and Urine $\mathrm{Ph}$

\section{Introduction}

Diabetes mellitus (DM) is a complex endocrine metabolic disorder associated with hyperglycemia which, commonly leads to alterations in the functions of several organs in the human body such as kidneys, eyes, nerves, gastrointestinal, hepatobiliary organs[1-3] .

Diabetes is due to either the pancreas not producing enough insulin (type 1), or because cells of the body do not respond properly to the insulin that is produced ( type 2 ) [4]

kidney stone formatted as a result of an imbalance between urinary-promoting and inhibiting factors (as in table 1). The substances that can be modified in practice at this time are citrate as an inhibiter, calcium, and PH as an promoters [5,6]. Diabetes has also been associated with endogenous oxalate synthesis, which is a mechanism of stone formation $[7,8]$.

Table 1 : Urinary-promoting and inhibiting factors.

\begin{tabular}{ll}
\hline Promoting factors & \multicolumn{1}{c}{ Inhibiting factors } \\
\hline Calcium & Inorganic \\
Sodium & Citrate \\
Oxalate & Magnesium \\
Urate & Pyrophosphate \\
Cystine & Organic \\
Low urine pH & Tamm-Horsfall protein \\
Tamm-Horsfall protein & Urinary Prothrombin fragment 1 \\
Low urine flow & Protease inhibitor: inter $\alpha$ inhibitor \\
& Glycosaminoglycans \\
& Osteopontin (Uropontin) \\
& Renal lithostathine \\
& Other Bikunin, Calgranulin \\
& High urine flow \\
\hline
\end{tabular}

Citrate, is a tricarboxylic acid, synthesized in mitochondria from oxaloacetate and acetyl-CoA by the enzyme citrate synthase[5,6]. When citrate present in urine forms soluble complexes with calcium leading to decrease the super saturation of calcium oxalate and 


\section{University of Thi-Qar Journal Vol.11 No.1 Mar 2016 \\ Web Site: https://jutq.utq.edu.iq/index.php/main Email: journal@jutq.utq.edu.iq}

calcium phosphate. In many studies involving patients with urinary tract stone disease the excretion of citrate is significantly low [9].

Calcium is a versatile intracellular messenger that is used throughout the life cycle of an organism to control diverse biological processes [10]. It has been suggested that diabetes is linked by a common defect of divalent cation metabolism, including calcium [11].

Calcium is important for insulin mediated intracellular processes in insulin responsive tissues such as adipose tissue and skeletal muscle with a very narrow range necessary for optimal insulin action because it's necessary for insulin receptor phosphorylation and proper signal transduction and thus optimal GLUT-4 transporter activity [12]. Diabetes mellitus is associated with a decrease in bone mineral content and increased urinary excretion of calcium and phosphate [13].

Defects in urinary acidification (excretion of inappropriately alkaline or acidic urines, respectively) contribute to kidney stone disease [14], so urine $\mathrm{pH}$ is an important factor in the production of kidney stones such as: uric acid, cystine, and calcium oxalate stones, which are tend to form in acidic urine, whereas struvite (magnesium ammonium phosphate) and calcium phosphate stones form in alkaline urine [15]

Several studies have evaluated urinary citrate levels in patients with urolithiasis and in normal individuals. The results have been conflicting; some have shown low urinary citrate output in stone formers as compared to controls [16-18], while other studies have shown no difference [19-21].

Also there is little data available on the relationship between fasting blood glucose , urine calcium and urine citrate in diabetes mellitus, on other hands a few studies were fond that type 1 , related with the presence of renal stone more than type 2 . This finding was in contrast with other findings which suggested that insulin resistance was a risk factor of renal stone [22,23].

So this study are design to estimate urinary value of calcium, citrate, and the $\mathrm{PH}$ then assess their relation with fasting blood sugar ( F.B.S ) level and type of diabetes mellitus disease to evaluate the most probability of calcium stones formation in diabetes patients dependent of their type (type 1 and type 2 ) .

\section{Patients and methods}

Fifty four diabetic patients selected with no history of hypertension, no heart disease , and no other disease or smoking. Fasting blood and 24 hour urine samples were collected to evaluate fasting blood sugar, urine calcium, urine citrate, and urine $\mathrm{PH}$. The parameters analyzed dependent to standard methods [24-27] . 


\section{Statistical analysis}

The data for biochemical analysis was subjected to standard statistical analysis using the Statistical Package for Social Science (SPSS) version 19, through using independent sample $t$ test for comparing between data base of diabetes patients and the correlation between parameters we used biveriate pearson, finally figures or curves done by using curve estimation options .

\section{Results}

Data descriptive of fifty four diabetes mellitus patients are presented in table 2, which show that patients consists of 30 male (55.6\%) and 24 women (44.4\%) in a total of 54 patients with diabetes mellitus, aged between 20-65 years . The statistic results of DM type are $25(46.3 \%)$ with type 1 and $29(53.7 \%)$ with type 2 .

Table 2: Data descriptive of fifty four diabetes mellitus patients.

\begin{tabular}{|l|l|}
\hline Characteristic of patients & Number (\%) \\
\hline $\begin{array}{l}\text { Gender } \\
\text { *Male } \\
\text { *Female }\end{array}$ & $\begin{array}{l}30(55.6 \%) \\
24(44.4 \%)\end{array}$ \\
\hline Age ,yr & $20-65 \mathrm{yr}$ \\
\hline $\begin{array}{l}\text { DM type } \\
\text { *Type 1 } \\
\text { *Type 2 }\end{array}$ & $25(46.3 \%)$ \\
$39(53.7 \%)$
\end{tabular}

In table 3, we can show values of F.B.S, urine calcium, urine citrate and urine $\mathrm{PH}$ for fifty healthy subjects and fifty four diabetic patients. F.B.S concentration $(11.79 \pm 4.66$ $\mathrm{mmol} / \mathrm{l})$ increased significantly $(\mathrm{P}<0.01)$ as compared to healthy individuals $(4.5 \pm 0.98$ $\mathrm{mmol} / \mathrm{l})$. 


\section{University of Thi-Qar Journal Vol.11 No.1 Mar 2016}

Web Site: https://jutq.utq.edu.iq/index.php/main Email: journal@jutq.utq.edu.iq

Also urine calcium significantly elevated $(\mathrm{P}<0.01)$ in diabetic patients $(6.184 \pm 1.67)$ the results were in the upper limit of normal range (2.5 - $6.2 \mathrm{mmol} /$ day ) [25].

Urine citrate significantly $(\mathrm{P}<0.01)$ decreased $(0.47 \pm 0.57)$ comparing with healthy individuals $(2.22 \pm 0.55)$, The mean urinary citrate excretion is $(3.34 \mathrm{mmol} / \mathrm{l}) 640 \mathrm{mg} / \mathrm{d}$ in healthy individuals [ 28]. Finally urine PH $(4.46 \pm 0.50)$ is significantly $(\mathrm{P}<0.05)$ lower than control $(6.16 \pm 0.38)$.

Table 3: The values of F.B.S, Urine Calcium, Urine Citrate, and urine PH for healthy subjects and diabetic patients .

\begin{tabular}{|l|l|l|}
\hline Urine Parameters & $\begin{array}{l}\text { Healthy individual } \\
(\mathrm{n}=50)\end{array}$ & $\begin{array}{l}\text { Diabetic patients } \\
(\mathrm{n}=54)\end{array}$ \\
\hline $\begin{array}{l}\text { Fasting Blood Sugar } \\
(\mathrm{mmol} / \mathrm{L})\end{array}$ & $4.5 \pm 0.98^{\mathrm{a}}$ & $11.79 \pm 4.66^{\mathrm{b}^{*}}$ \\
\hline $\begin{array}{l}\text { Urine Calcium (mmol/ day) } \\
\text { Urine Citrate (mmol/ day) }\end{array}$ & $4.11 \pm 0.88^{\mathrm{a}}$ & $6.18 \pm 1.67^{\mathrm{b}^{*}}$ \\
\hline Urine PH & $6.16 \pm 0.38^{\mathrm{a}}$ & $0.47 \pm 0.57^{\mathrm{b}^{*}}$ \\
\hline
\end{tabular}

*Each value represents mean \pm SD values with non identical superscript ( a , b or c ...etc.) were considered significantly different $(\mathrm{P} \leq \mathbf{0 . 0 1}), * *$ significantly different $(\mathrm{P} \leq \mathbf{0 . 0 5})$.

The correlation between F.B.S and urinary calcium can be shown in figure 1, there are a positive correlation between F.B.S and urine calcium for all patients. but figure 2 shows adverse correlation between F.B.S. and urine citrate. 


\section{University of Thi-Qar Journal Vol.11 No.1 Mar 2016}

Web Site: https://jutq.utq.edu.iq/index.php/main Email: journal@jutq.utq.edu.iq

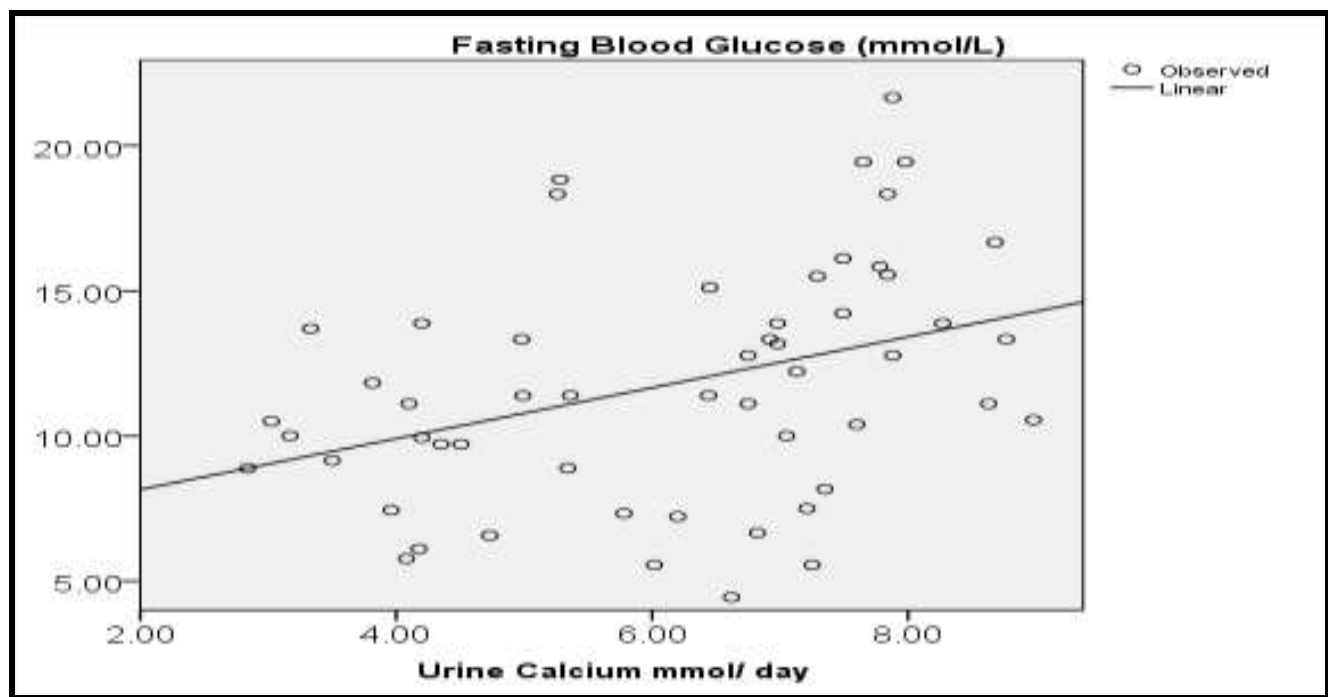

Figure 1 : The correlation between F.B.S and urine calcium.

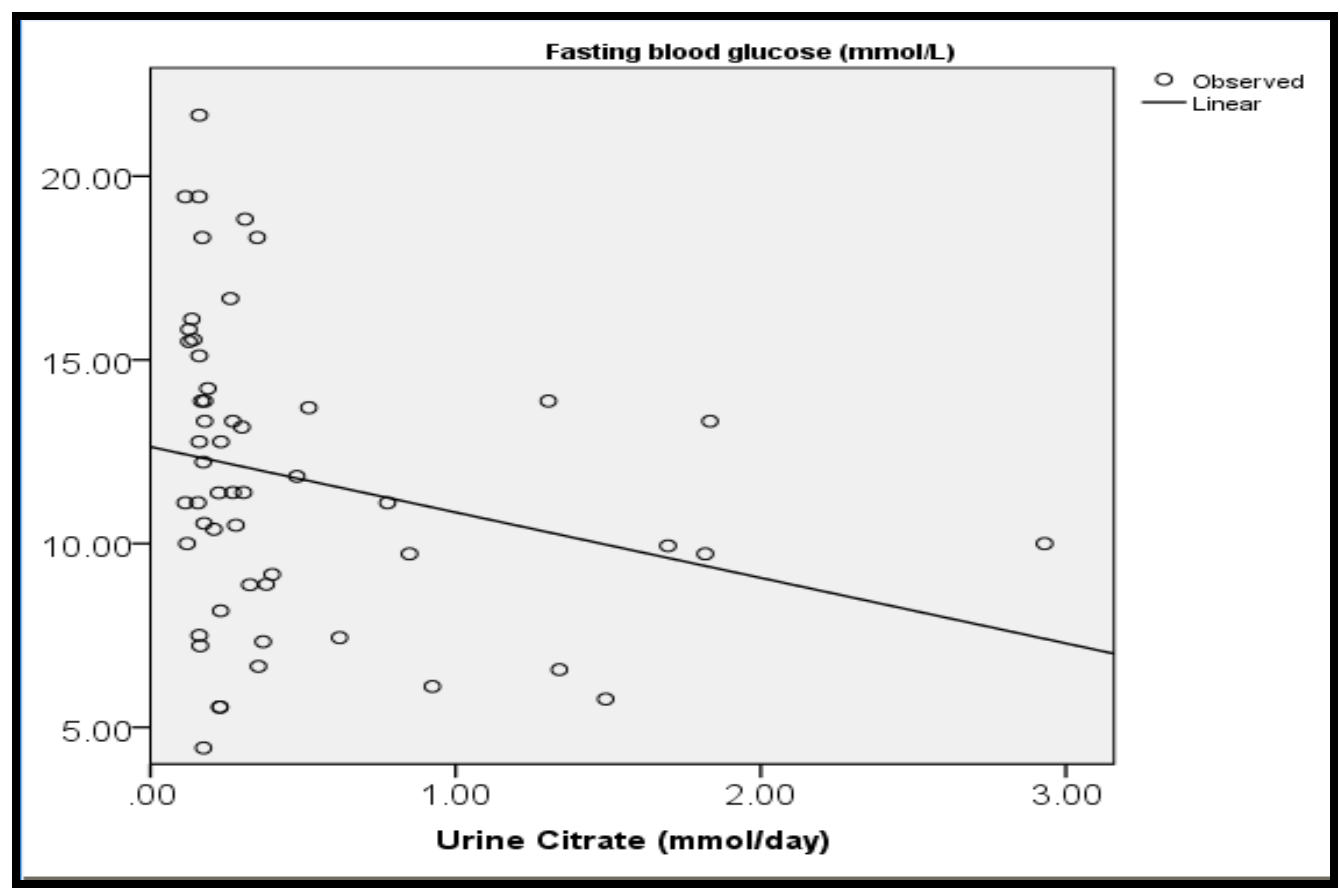

Figure 2: The correlation between F.B.S. and urine citrate.

The comparing results for all parameters between both diabetes patients type are presented in table 4 . There are no significant differences $(\mathrm{P}>0.05)$ in FBS and urine calcium except in urine citrate $(\mathrm{P}<0.01)$, and urine $\mathrm{PH}(\mathrm{P}<0.05)$ significantly decreased in type 2. 


\section{University of Thi-Qar Journal Vol.11 No.1 Mar 2016}

Web Site: https://jutq.utq.edu.iq/index.php/main Email: journal@jutq.utq.edu.iq

Table 4: The relation between diabetic type and the value of F.B.S, urine calcium, urine citrate and PH for diabetic patients.

\begin{tabular}{|c|c|c|}
\hline Parameters & DM type 1 $(\mathrm{n}=25)$ & DM type 2 $(\mathrm{n}=29)$ \\
\hline F.B.S & $11.185 \pm 3.76^{\mathrm{a}}$ & $12.31 \pm 4.3^{\mathrm{a}}$ \\
\hline Urine calcium & $5.99 \pm 1.83^{\mathrm{a}}$ & $6.27 \pm 1.64^{\mathrm{a}}$ \\
\hline Urine citrate & $0.61 \pm 0.72^{\mathrm{a}}$ & $0.35 \pm 0.36^{\mathrm{b}_{*}}$ \\
\hline Urine PH & $5.0 \pm 0.71^{\mathrm{a}}$ & $4.12 \pm 0.44^{\mathrm{b}^{* *}}$ \\
\hline
\end{tabular}

*Each value represents mean \pm SD values with non identical superscript ( a , b or c ...etc.) were considered significantly different $(\mathrm{P}<0.01),{ }^{* * *}$ significantly different $(\mathrm{P}<0.05)$.

\section{Discussion}

Both types of diabetic patients have increasing with no significant differences in urine calcium concentration and its concentration increased with the increasing of fasting blood glucose level. But its level in the upper limit of normal range (2.5 - $6.2 \mathrm{mmol} /$ day ). In this state patients will be under risk of hypercalciuria and the precise cause of this, that uncontrolled blood glucose may be stimulate parathyroid hormone, leading to reduce the tubular reabsorption of calcium, increase urinary losses of calcium and finally the negative calcium balance in body [29-31].

The positive relation between blood glucose and urine calcium (figure 1) provide a direct evidence of a rise in cytosolic free calcium concentration depends on glucose metabolism and is a primary signal for insulin secretion[32-35], so the severity of stone formation increased with hyperglycemia degree and to the low blood glucose control, which might contribute in addition of stone also to the development of osteopenia [36].

In fifty four diabetic mellitus patients urine citrate significantly decreased $(\mathrm{P}<0.01)$ but adversely related with fasting blood glucose level, and on other hand, its concentration in patients with type 2 is significantly lower than type $1(\mathrm{P}<0.01)$.

Hypocitraturia, defined as urinary citrate excretion less than $1.67 \mathrm{mmol}(320 \mathrm{mg}$ ) per day for adults, is a common metabolic abnormality in stone formers, occurring in $20 \%$ to 60\%.[37] 


\section{University of Thi-Qar Journal Vol.11 No.1 Mar 2016 \\ Web Site: https://jutq.utq.edu.iq/index.php/main Email: journal@jutq.utq.edu.iq}

Modulation of citrate excretion in the kidney is influenced by multiple factors; however, $\mathrm{pH}$ (systemic, tubular, and intracellular) has the strongest impact [38]. Although the majority of patients have idiopathic hypocitraturia, there are a number of causes for this abnormality, including distal renal tubular acidosis, hypokalemia, bowel dysfunction, a highprotein, and low-alkali diet. Other factors associated with altered citrate excretion include genetic factors, certain drugs, renal insufficiency, hyperaldosteronism, type I glycogen storage disease, and exercise [39].

Management of hypocitruturia by high fluid and citrus fruit intake, normal calcium consumption, and restriction of sodium, oxalate, animal protein, and fructose intake. The administration of citrate preparations or other alkali has been demonstrated to benefit hypocitraturic stone formers. Although many forms of citrate have been used for these patients (potassium citrate, sodium citrate, potassium-magnesium-citrate), potassium citrate has emerged as the most beneficial [40].

Patients who either cannot tolerate or cannot afford potassium citrate may benefit from consuming citrus juices, which contain significant amounts of citrate [39,41]. Most of the orally ingested citrate gets converted to bicarbonate conferring alkali load which may result in increased urine-pH depending concomitant acid load. Despite being richer in citrate, lime, lemon or lemonade generally do not increase urinary $\mathrm{pH}$ ( 0.1 point increase $)$ presumably due to acidic nature, whereas orange juice does by $0.6-0.8$ points, similar to potassium-citrate (Kcit) $][42,43]$

Another finding of this study was that, the urine acidity increased significantly $(\mathrm{P}<0.05)$ in diabetes patients, and especially in patients with type 2 . Insulin therapy may modify urine $\mathrm{pH}$ independent of glycemic control [44], but Insulin resistance may reduce ammonium excretion by the proximal tubule, where high luminal calcium concentrations stimulate urinary acidification and reduce urinary concentration via a calcium-sensing receptor, resulting in the excretion of acidic and diluted urine [14].

Finally we can concluded that, poorly controlled of hyperglycemia increased the risk of urinary stone by increasing hypercalciuria, hypocitruturia, and urine acidity . Urine citrate concentration and $\mathrm{PH}$ level are more sensitive to the metabolic changes in diabetes patients and correlated with type of disease, their levels in type 2 are significantly lower than type 1 , so both diabetes patients have relative risk of prevalent stone disease but type 2 diabetic patients predisposes to calcium Urolithiasis more than type 1. These findings may be helpful in further elucidating the etiology of urolithiasis. and assessment provide information about stone-forming factors that can guide prevention in diabetes mellitus patients..

\section{References}




\section{University of Thi-Qar Journal Vol.11 No.1 Mar 2016}

Web Site: https://jutq.utq.edu.iq/index.php/main Email: journal@jutq.utq.edu.iq

1. Taylor EN1, Stampfer MJ, Curhan GC. Diabetes mellitus and the risk of nephrolithiasis. .Kidney Int. 2005 Sep;68(3):1230-5.

2. R. A. DeFronzo, M. Goldberg, and Z. A. Agus, J. Clin, Invest. 58:83. 1976.

3. P. Raskin, M. R. M. Stevenson, D. E. Barilla, and C. Y. C. Pak, Clin. Endocrinol. 1978 $.9: 329$

4. Shoback, edited by David G. Gardner, Dolores (2011). Greenspan's basic \& clinical endocrinology (9th ed.). New York: McGraw-Hill Medical. pp. Chapter 17.

5. Krebs HA, Johnson WA. The role of citric acid in intermediate metabolism in animal tissues. FEBS Lett. 1980;117(suppl):K1-K10.

6. Krebs HA, Salvin E, Johnson WA. The formation of citric and alpha-ketoglutaric acids in the mammalian body. Biochem J. 1983;32:113-117.

7. Gorbachinsky I, Akpinar H, Assimos DG (2010) Metabolic syndrome and urologic diseases. Reviews in urology 12: e157-80 .

8. Worcester EM, Gillen DL, Evan AP, Parks JH, Wright K, et al. (2007) Evidence that postprandial reduction of renal calcium reabsorption mediates hypercalciuria of patients with calcium nephrolithiasis. American journal of physiology Renal physiology 292: F66-75 .

9. Chapman BA, Wilson IR, Frampton CM, Chisholm RJ, Stewart NR, Eagar GM, et al. Prevalence of gallbladder disease in diabetes mellitus. Dig Dis Sci. 1996;41:2222-8.

10. Berridge MJ, Lipp P, Bootman MD: The versatility and universality of calcium signalling. Nat Rev Mol Cell Biol1.2000:11 -21,

11. Resnick LM: Hypertension and abnormal glucose homeostasis: possible role of divalent ion metabolism. Am J .1989.Med87 :17S -22S,

12. Ojuka EO. Role of calcium and AMP kinase in the regulation of mitochondrial biogenesis and GLUT4 levels in muscle. Proc Nutr Soc. 2004;63:275-278.

13. Fogh-Andersen N, McNair P, Møller-Petersen J, Madsbad S. Serum calcium fractions in diabetes mellitus. Clin Chem. 1982; Oct;28(10):2073-6.

14. Mithani S1, Zaidi Z. Comparison of 24 hours urinary citrate levels in urolithiasis patients and healthy controls. J Pak Med Assoc. 2005 Sep;55(9):371-3.

15. Lynda Frassetto and Ingrid Kohlstadt : Treatment and Prevention of Kidney Stones: Am Fam Physician. 2011 Dec 1;84(11):1234-1242.

16. Schwille PO, Scholz D, Paulus M, Engelhardt W, Sigel A. Citrate in daily and fasting urine. Results of controls, patients with recurrent idiopathic calcium urolithiasis and primary hyperparathyroidism. Invest Urol 1979; 16: 457-462. 


\section{University of Thi-Qar Journal Vol.11 No.1 Mar 2016}

Web Site: https://jutq.utq.edu.iq/index.php/main Email: journal@jutq.utq.edu.iq

17. Elliot JS, Riberiro Me. The urinary excretion of citric, hippuric and lactic acid in normal adults and in patients with calcium oxalate urinary calculus disease. Invest Urol $.1972 ; 102-106$.

18. Welschman SG, Mc Geown. Urinary citrate excretion in stone formers and normal controls. Br J Urol, 1976; 48: 7-11.

19. Francois B, Cahen R, Pascal B. Inhibitors of urinary stone formation in 40 recurrent stone formers. Br J Urol, 1986; 58: 479-483.

20. Abraham PA, Smith CL. Evaluation of factors involved in calcium stone formation. Miner Elect Metab .1987; 13: 201-208.

21. Sidhu H, Vaidyanathan S, Wangoo D, Thind SK, Nath R, Malakondaiah GC, et al. A comparative study of circadian rhythmicity in urinary citrate excretion in healthy men and male patients with calcium nephrolithiasis. Ind J Urol .1991; 8: 10-13.

22. West B, Luke A, Durazo-Arvizu RA, Cao G, Shoham D, Kramer H. Metabolic syndrome and self-reported history of kidney stones: the National Health and Nutrition Examination Survey (NHANES III) 1988-1994. Am J Kidney Dis. 2008;51:741-747.

23. Lieske JC, de la Vega LS, Gettman MT, Slezak JM, Bergstralh EJ, Melton LJ, 3rd, Leibson CL. Diabetes mellitus and the risk of urinary tract stones: a population-based case-control study. Am J Kidney Dis. 2006;48:897-904.

24. Trinder, P.A. Clin.Biochem. $1969 ; 6: 24$.

25. Lorentz, K. Improved determination of serum calcium with 2-cresolphthalein Complexone. Clinica Chimica Acta, 1982. 126, 327-334.

26. Millan A, Conte A, Garcia-Raso A, Grases F Determination of citrate in urine by simple direct photometry. Clin Chem .1987. 33:1259-1260.

27. Free AH, Free H. urinalysis, Critical discipline of clinical science. CRC Crit.Rev. Clin.Lab.Sci. 1972. 3(4):481 - 531,

28. 265

29. Kerstetter, J, Caballero, B, O'brien, K, et al: Mineral homeostasis in obesity: Effects of euglycemic hyperinsulinemia. Metabolism .1991 .40:707-713.

30. Shimamoto, K, higashiura, K, nakagawa, M, et al: Effects of hyperinsulinemia under the euglycemic condition on calcium and phosphate metabolism in non-obese normotensive subjects. Tohoku J Exp Med 1995 177:271-278.

31. nowicki, M, kokot, F, surdacki, A: The influence of hyperinsulinaemia on calciumphosphate metabolism in renal failure. Nephrol Dial Transplant 1998 .13:2566-2571.

32. Sun G1, Vasdev S, Martin GR, Gadag V, Zhang H. Altered calcium homeostasis is correlated with abnormalities of fasting serum glucose, insulin resistance, and beta-cell function in the Newfoundland population. Diabetes. 2005. Nov;54(11):3336-9. 


\section{University of Thi-Qar Journal Vol.11 No.1 Mar 2016}

Web Site: https://jutq.utq.edu.iq/index.php/main Email: journal@jutq.utq.edu.iq

33. dos Santos LC1, de Pádua Cintra I, Fisberg M, Martini LA. Calcium intake and its relationship with adiposity and insulin resistance in post-pubertal adolescents. J Hum Nutr Diet. 2008 .Apr;21(2):109-16.

34. Baris Afsar and Halit Karaca. The relationship between insulin, insulin resistance, parathyroid hormone, cortisol, testosterone, and thyroid function tests in the presence of nephrolithiasis: a comprehensive analysis Cent. European J Urol. 2014; 67(1): 5864. .

35. Monitoring of Hypocalcaemia and Hyperglycemia predictive consequences of Thyroidectomy Syed Wasif Gillani1*, Diana Laila Rahmatillah2, Yelly Oktavia Sari1, Mirza R Baig3 and Syed Azhar Syed Sulaiman4. International Archives of Medicine 2014, 7:13 doi:10.1186/1755-7682-7-13.

36. WHO Scientific Group on the Prevention and Management of Osteoporosis (2000) : Geneva, Switzerland) (2003). "Prevention and management of osteoporosis : report of a WHO scientific group".

37. Pak CY. Etiology and treatment of urolithiasis. Am J Kidney Dis. 1991;18:624-637

38. Crawford MA, Milne MD, Scribner BH. The effects of changes in acid-base balance on urinary citrate in the rat. $J$ Physiol. 1959;149:413-423.

39. Jack M Zuckerman, and Dean G Assimos, Hypocitraturia: Pathophysiology and Management. Medical Rev Urol. 2009 Summer; 11(3): 134-144.

40. Ekeruo WO, Tan YH, Young MD, et al. Metabolic risk factors and the impact of medical therapy on the management of nephrolithiasis in obese patients. J Urol. 2004;172:159-163.

41. Thalassinos NC1, Hadjiyanni P, Tzanela M, Alevizaki C, Philokiprou D. Calcium metabolism in diabetes mellitus: effect of improved blood glucose control. Diabet Med. 1993 May;10(4):341-4.

42. Kang DE, Sur RL, Haleblian, GE, Fitzsimons NJ, Borawski KM, Preminger GM. Long-term lemonade based dietary manipulation in patients with hypocitraturic nephrolithiasis. .J Urol 2007;177:1358-62.

43. Wabner CL, Pak CY. Effect of orange juice consumption on urinary stone risk factors. J Urol 1993;149:1405-8.

44. Fabio C.M. Torricellia, b, c, Shubha Dea, b, c, Surafel Gebreselassiea, b, c, Ina Lia, b, c, Carl Sarkissiana, b, c, Manoj Mongaa, b, c, , Endourology and Stones ,Type-2 Diabetes and Kidney Stones: Impact of Diabetes Medications and Glycemic Control Show more, Volume 84, Issue 3, September 2014, Pages 544-548 